\title{
A locus for hereditary hypotrichosis localized to human chromosome 18q21.1
}

\author{
Muhammad Arshad Rafique ${ }^{1}$, Muhammad Ansar ${ }^{1}$, Syed Muhammad Jamal ${ }^{1}$, Sajid Malik ${ }^{1}$, \\ Muhammad Sohail ${ }^{2}$, Mohammad Faiyaz-Ul-Haque ${ }^{3}$, Sayedul Haque ${ }^{1}$, Suzanne M Leal ${ }^{4}$ \\ and Wasim Ahmad*,1
}

${ }^{1}$ Department of Biological Sciences, Quaid-I-Azam University, Islamabad, Pakistan; ${ }^{2}$ Department of Biochemistry, University of Oxford, UK; ${ }^{3}$ The Hospital for Sick Children, Toronto, Ontario, Canada; ${ }^{4}$ Department of Molecular and Human Genetics, Baylor College of Medicine, Houston, TX, USA

Hereditary hypotrichosis is a rare autosomal recessive condition characterized clinically by alopecia. Three consanguineous kindreds with multiple affected individuals were ascertained from different regions of Pakistan. A novel hypotrichosis locus was mapped to a $5.5 \mathrm{cM}$ region on chromosome 18q21.1. A maximum two-point LOD score of 5.25 was obtained at marker D18S36 $(\theta=0.0)$. Three genes each for desmoglein and desmocollin proteins are located in this region. The expression in epidermal desmosomes and their connection to the keratin intermediate filaments make these genes excellent candidates for recessive hypotrichosis.

European Journal of Human Genetics (2003) 11, 623-628. doi:10.1038/sj.ejhg.5201005

Keywords: autosomal recessive hypotrichosis; 18q21.1; desmogleins; desmocollins

\section{Introduction}

There are many forms of hereditary hypotrichosis and alopecia, showing variation in terms of the age of onset, severity and associated abnormalities. Only a small number of causative genes for this trait have been identified and/or localized. Congenital atrichia (MIM 203655) is a rare, recessive inherited form of total alopecia that results from failure to initiate the first adult catagen. The salient features of this disorder are that affected individuals are completely devoid of scalp hair, eyebrows, eyelashes, axillary and pubic hair. Several mutations have been identified in the human homologue of the mouse hairless gene in atrichia families. ${ }^{1-4}$ In contrast to the total and permanent absence of hair in congenital atrichia, hair is present in hereditary hypotrichosis simplex but is diffusely thinned. Hypotrichosis simplex (MIM 146520) can affect

*Correspondence: Dr W Ahmad, Department of Biological Sciences, Quaid-I-Azam University, Islamabad, Pakistan. Tel: + 92-51-2821643; Fax: +92-51-9205753; E-mail: wahmad@mail.qau.edu.pk

Received 9 October 2002; revised 5 February 2003; accepted 12 March 2003 all body hair or be limited to the scalp. ${ }^{5,6}$ The locus for hypotrichosis simplex (HSS) was mapped to chromosome 6p21.3. ${ }^{6}$ Marie Unna hereditary hypotrichosis (MUHH) $)^{7,8}$ (MIM 146550) is distinguished from hypotrichosis simplex by the presence of a twisting hair dystrophy. This form of hypotrichosis is characterized by loss of hair on the scalp, eyebrows, eyelashes, and body. MUHH manifests itself in the first decade of life and progresses to almost complete alopecia. MUHH was localized to a $6.6 \mathrm{cM}$ region on $8 \mathrm{p} 21 ;{ }^{9,10}$ however, no mutations were found in the hairless gene, which lies in this interval. An autosomal dominant form of hypotrichosis simplex (MIM 605389) was localized to chromosome $18 \mathrm{p} 11.32-\mathrm{p} 11.23 .{ }^{11} \mathrm{~A}$ form of alopecia, monilethrix (MIM 158000), was localized to chromosome $12 \mathrm{q} 13$ and is due to mutations in the hair cortex keratin gene HB1 or HB6. ${ }^{12}$ The severity of alopecia is variable from patient to patient and is also variable over time in the same individual. Perifollicular hyperkeratosis is a consistent feature of monilethrix.

Mutations in winged-helix-nude (whn) gene (MIM 600838) at the 'nude' locus of mice and rats disrupt normal hair growth and thymus development, causing 
nude mice and rats to be immune-deficient. ${ }^{13}$ In humans a nonsense mutation was identified in the homologue of the mouse whn gene, in two sisters who were born with a complete absence of scalp hair, eyebrows and eyelashes and had dystrophic nails and immunological abnormalities. ${ }^{14}$ Netherton syndrome (MIM 256500) is a rare autosomal recessive disease characterized by the presence of bamboo hair, congenital ichthyosis and trichorrhexis invaginata. ${ }^{15,16}$ The locus for Netherton syndrome was mapped to $5 \mathrm{q} 32 .^{17}$

In the present study we describe three consanguineous families from Pakistan presenting an autosomal recessive form of hypotrichosis. The gene responsible for this specific form of hypotrichosis was localized to chromosome $18 \mathrm{q} 21.1$.

\section{Materials and methods Family history}

Three consanguineous kindreds (LAP1, LAP2 and LAP3) from Pakistan, with hypotrichosis segregating as a single Mendelian abnormality without associated ectodermal defects (Figure 1), were studied. Before the onset of the study, approval was obtained from the Quaid-I-Azam University Institutional Review Board. Informed consent was obtained from all individuals who agreed to participate in the study. The pedigree structure is based upon interviews with multiple family members. All three pedigrees (Figure 1) provided convincing evidence for an autosomal recessive mode of inheritance. Family members rarely marry outside the community and consequently consanguineous unions are common. Therefore, it is highly likely that all affected individuals within the same kindred will be homozygous for the same mutation. Affected individuals were all in good general health with no evidence of immune system dysfunction or unusual susceptibility to skin tumors. At birth, hair was present on the scalp, but regrew sparsely after ritual shaving, which is usually performed a week after birth. Affected persons are nearly devoid of normal eyebrows and eyelashes; however, axillary and pubic hairs are normal (Figure 2a). Affected male individuals have normal beard hair; however, hair is absent on the legs and arms.

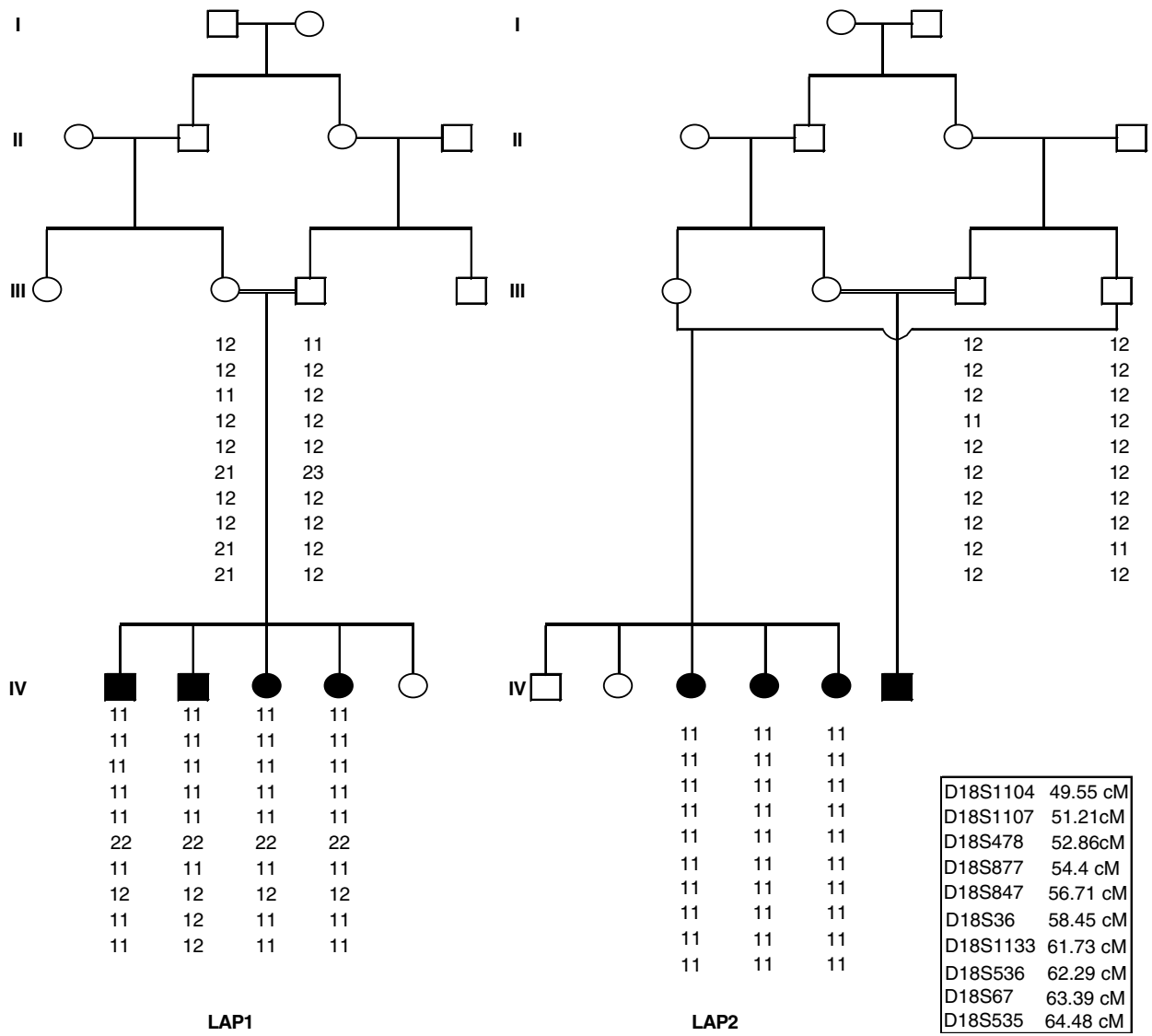

Figure 1 Pedigree of the families LAP1, LAP2 and LAP3 showing disease-associated haplotypes. Black circles and squares represent affected females and males, respectively. The marker order is indicated in the inset. 


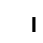

II

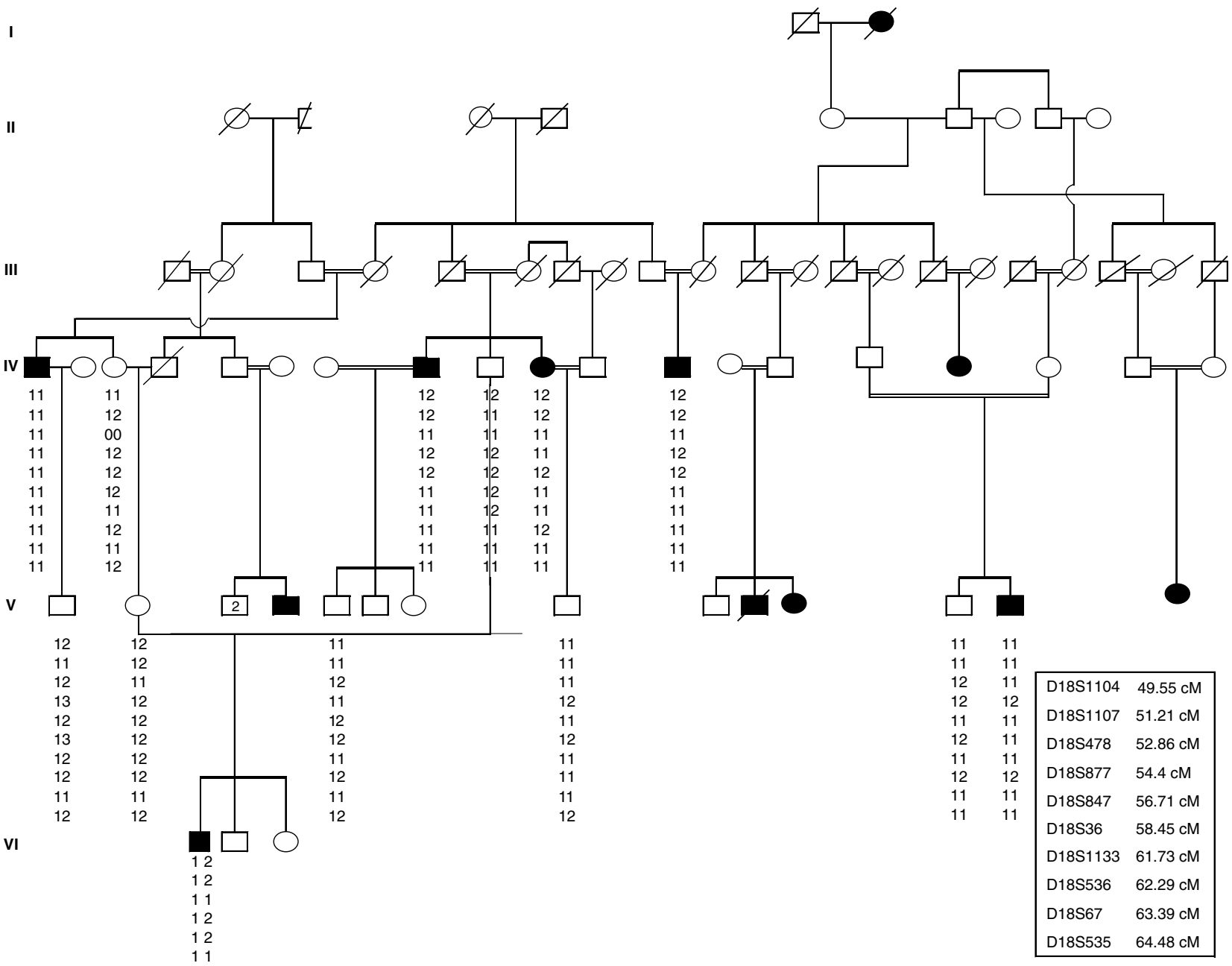

Figure 1 (Continued).

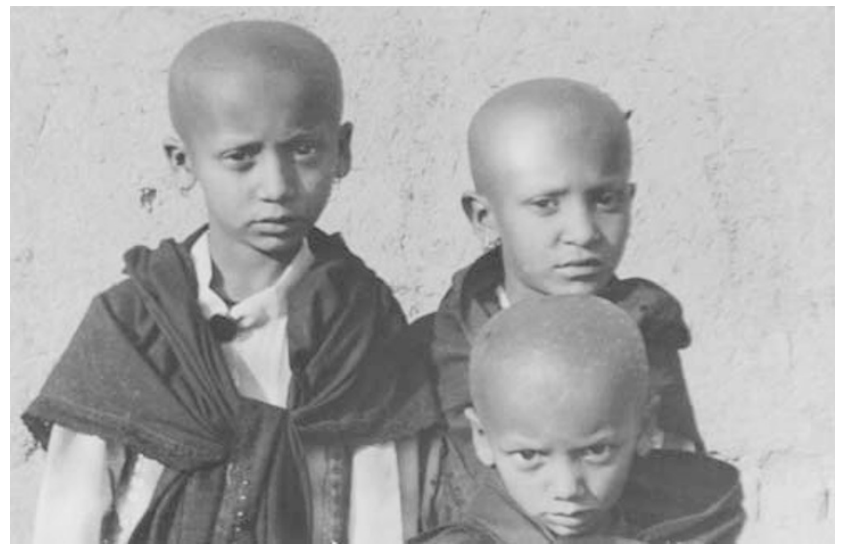

Figure 2 Clinical presentation of LAP phenotype. Affected individuals (IV $-3-5$ ) of family LAP2.
Linkage analysis

Two-point linkage analysis was carried out using MLINK of the FASTLINK computer package. ${ }^{18}$ For the analysis an autosomal recessive mode of inheritance with complete penetrance and a disease allele frequency of 0.001 was assumed. The marker-allele frequencies were estimated from the data by means of both observed and reconstructed genotypes of founders within this pedigree.

\section{DNA extraction and genotyping}

Genomic DNA was extracted from peripheral-blood samples collected from both affected and unaffected family members by established procedures. PCR reactions were carried out in $25 \mu \mathrm{l}$ reaction volumes containing $40 \mathrm{ng}$ genomic DNA, $20 \mathrm{pmol}$ of primers, $200 \mu \mathrm{M}$ of each dNTP, $1 \mathrm{U}$ of Taq DNA Polymerase (MBI Fermentas, UK) and $2.5 \mu \mathrm{l}$ 
Table 1 Two-point LOD score results between the hereditary hypotrichosis locus and chromosome 18 markers

\begin{tabular}{|c|c|c|c|c|c|c|c|c|c|}
\hline \multirow[b]{2}{*}{ Marker } & \multirow[b]{2}{*}{ Genetic distance } & \multirow[b]{2}{*}{ Physical distance } & \multicolumn{7}{|c|}{$\angle O D$ score at $\theta=$} \\
\hline & & & 0.0 & 0.01 & 0.05 & 0.10 & 0.20 & 0.30 & 0.40 \\
\hline D18S1104 & $49.55 \mathrm{cM}$ & 1893503 & -1.68 & 0.98 & 1.40 & 1.37 & 1.05 & 0.64 & 0.25 \\
\hline D18S1107 & $51.21 \mathrm{cM}$ & 2192059 & -5.10 & 1.93 & 2.32 & 2.21 & 1.64 & 0.96 & 0.31 \\
\hline D18S478 & $52.86 \mathrm{cM}$ & 2498207 & 2.37 & 2.31 & 2.07 & 1.77 & 1.20 & 0.68 & 0.25 \\
\hline D18S877 & $54.4 \mathrm{cM}$ & 2655981 & $-\infty$ & 0.34 & 1.54 & 1.76 & 1.46 & 0.89 & 0.30 \\
\hline D18S847 & $56.71 \mathrm{cM}$ & 2762575 & -0.79 & 1.86 & 2.23 & 2.11 & 1.58 & 0.93 & 0.30 \\
\hline DSC3 & $\mathrm{N} / \mathrm{A}$ & 2859397 & & & & & & & \\
\hline DSC2 & $\mathrm{N} / \mathrm{A}$ & 2867039 & & & & & & & \\
\hline DSC1 & $\mathrm{N} / \mathrm{A}$ & 2873215 & & & & & & & \\
\hline DSG1 & N/A & 2892101 & & & & & & & \\
\hline D18S36 & $58.45 \mathrm{cM}$ & 2908715 & 5.25 & 5.11 & 4.55 & 3.86 & 2.57 & 1.44 & 0.52 \\
\hline DSG3 & $\mathrm{N} / \mathrm{A}$ & 2905071 & & & & & & & \\
\hline DSG2 & $\mathrm{N} / \mathrm{A}$ & 2912116 & & & & & & & \\
\hline D18S1133 & $61.73 \mathrm{cM}$ & 3203195 & 4.41 & 4.30 & 3.85 & 3.31 & 2.24 & 1.23 & 0.40 \\
\hline D18S536 & $62.29 \mathrm{cM}$ & 3152170 & $-\infty$ & -1.58 & 0.05 & 0.41 & 0.36 & 0.17 & 0.06 \\
\hline D18S67 & $63.39 \mathrm{cM}$ & 3595430 & $-\infty$ & -0.09 & 0.46 & 0.57 & 0.49 & 0.28 & 0.07 \\
\hline D18S535 & $64.48 \mathrm{cM}$ & $\mathrm{N} / \mathrm{A}$ & $-\infty$ & -0.04 & 1.03 & 1.22 & 1.02 & 0.60 & 0.18 \\
\hline
\end{tabular}

The markers displayed in bold flank the genetic region for the inherited hypotrichosis locus. Genetic map distances for marker loci are given according to the Marshfield map. Sequence-based physical map distances are given for the marker loci and the desmoglein and desmocollin genes according to the Human Genome Project - Santa Cruz (June 2002 release).

reaction buffer $\left(\mathrm{KCl} 50 \mathrm{~mm}\right.$, Tris-Cl $\left.\mathrm{pH} 8.3,1.5 \mathrm{mM} \mathrm{MgCl}_{2}\right)$. The thermal cycling conditions used included $95^{\circ} \mathrm{C}$ for $5 \mathrm{~min}$, followed by 40 cycles of $95^{\circ} \mathrm{C}$ for $1 \mathrm{~min}, 55-57^{\circ} \mathrm{C}$ for $1 \mathrm{~min}, 72^{\circ} \mathrm{C}$ for $1 \mathrm{~min}$ and a final extension at $72^{\circ} \mathrm{C}$ for $10 \mathrm{~min}$. PCR was performed by the use of thermal cycler 'Gene Amp PCR system 2400' obtained from Applied Biosystem (USA). The amplified products were resolved on $8 \%$ nondenaturing polyacrylamide gel and visualized by ethidium bromide staining to score the alleles by manual inspection. All individuals for whom a DNA sample was available were genotyped.

\section{Results}

A candidate gene approach was used to localize the hypotrichosis locus segregating in these families. Microsatellite markers were selected based on their location within candidate regions. The candidate gene regions that were screened included the region for the human hairless gene on chromosome $8 \mathrm{p} 12,{ }^{1,19}$ ectodermal dysplasia loci on chromosomes $2 \mathrm{q} 11-\mathrm{q} 13,11 \mathrm{q} 23$ and $13 \mathrm{q}^{20-22}$ Additionally, chromosomes 12 and 17 were screened, because a number of candidate genes including keratin and nail dyspalsia genes were mapped to these chromosomes. ${ }^{23,24}$ However, none of these regions displayed linkage to the hypotrichosis locus segregating in our kindreds. Markers located within the $18 \mathrm{q} 21$ region were then genotyped, since this region contains the desmoglein and desmocollin genes.

Significant evidence of linkage was obtained for marker D18S36 that localizes to the candidate $18 \mathrm{q} 21$ region. In order to fine map the locus, a total of 11 markers from this region were selected. ${ }^{25}$ For the three kindreds, a maximum two-point LOD score of $5.25(\theta=0)$ was obtained at marker
D18S36. The combined LOD scores obtained from the three families are summarized in Table 1. In family LAP3, recombination events were observed in affected individuals at markers D18S847 and D18S536, which localized the disease locus in a $5.57 \mathrm{cM}$ interval between these two markers. In addition, this region was homozygous in all affected individuals in each of the three pedigrees (Figure 1).

\section{Discussion}

The candidate interval for recessive hypotrichosis on 18q21.1 identified in the present study contains three desmoglein genes (see Table 1), designated DSG1, DSG2 and DSG3, as well as three desmocollin genes, DSC1, DSC2 and DSC3. In addition, this region also contains genes encoding transthyrectin, galactosyl transferase, meprin A and nucleolar protein 4. Desmoglein and desmocollin genes localize to a very small region $(150 \mathrm{~kb})$ on chromosome $18 \mathrm{q} 21.1,{ }^{26,27}$ suggesting that they may be subject to a mechanism of coordinate regulation, similar to the mechanism that is speculated for the epidermal differentiation complex. ${ }^{28}$ Both desmoglein and desmocollins are the glycoproteins of desmosomes, which are the most common type of intercellular junctions mediating cellto-cell adhesion in vertebrate epithelial cells. ${ }^{29}$ Different members of the human desmoglein and desmocollin genes are differentially expressed in the epidermis, perhaps reflecting strata-specific adhesive properties of these junctions and suggesting that they may function in epithelial differentiation. ${ }^{29,30}$ As members of the cadherin superfamily, the desmoglein and desmocollin genes possess similar structural functional domains, including sites for adhesion recognition, calcium binding, membrane inte- 
gration, cytoskeletal interactions and post-translational modifications, such as phosphorylations, glycosylation and proteolysis. ${ }^{29}$ Therefore, in addition to their functions as static adhesive proteins, they also function as dynamic mediators of morphogenesis during embryonic development and are modulated in response to signals such as calcium concentration, cell differentiation, motility and potentially involved in disease phenotypes. ${ }^{30}$ Certain members of the desmosomal cadherin family have already been implicated in a number of acquired and inherited skin diseases. The severe acantholytic diseases pemphigus vulgaris and pemphigus foliaceous result from antibody production against desmoglein 3 and desmoglein 1, respectively. ${ }^{31,32}$ Antibodies against desmocollin-1 cause a distinct acantholytic phenotype known as subcorneal pustular dermatosis type of IgA pemphigus. ${ }^{33}$

Recently, a study revealed the differential expression pattern of desmogleins and desmocollins in the cell types of the developing and adult human hair follicles, suggesting that although these genes show homology, they may have distinct roles in hair follicle morphogenesis and hair cycling. ${ }^{34}$ Mutations in the mouse desmoglein-3 gene lead to the balding phenotype characterized by hair loss, skin fragility and oral lesions. ${ }^{34}$ Their expression in epidermal desmosomes and hair follicles and in addition their connections to the keratin intermediate filaments make them excellent candidate genes for recessive hypotrichosis.

\section{Electronic-database information}

The URLs for data presented herein are as follows: UCSC Human Genome Project Working Draft, June 2002 assembly, http://genome.cse.ucsc.edu/ (for the physical positions of STRP loci and desmoglein and desmocollin genes); Marshfield Center for Medical Genetics, http:// www.marshmed.org/genetics/ (for the order and genetic distances of STRP loci on 18q).

\section{Acknowledgements}

We sincerely thank the family members who participated in this study. This work was supported by the Biotechnology Commission of Pakistan - Ministry of Science \& Technology, Third World Academy of Sciences (TWAS) - Italy and Pakistan Science Foundation (PSF).

\section{References}

1 Ahmad W, Haque MF, Lam HM et al: Alopecia Universalis associated with a mutation in the human hairless gene. Science 1998; 279: 720-724.

2 Ahmad W, Invine A, Lam HM et al: A missense mutation in the zinc-finger domain of the human hairless gene underlies congenital atrichia in a family of irish travellers. Am J Hum Genet 1998; 63: 984-989.

3 Ahmad W, Zlotogorski A, Andrie A et al: Genomic organization of the human hairless gene and identification of a mutation underlying congenital atrichia in an Arab Palestinian family. Genomics 1999; 56: 141-148.
4 Cichon S, Anker M, Vogt IR et al: Cloning, genomic organization, alternative transcripts and mutational analysis of the gene responsible for autosomal recessive universal congenital alopecia. Hum Mol Genet 1998; 7: 1671-1679.

5 Toribio J, Quinones PA: Hereditary hypotrichosis simplex of the scalp - evidence for autosomal dominant inheritance. $\mathrm{Br} J$ Dermatol 1974; 91: 687-696.

6 Betz RC, Lee YA, Bygum A et al: A gene for hypotrichosis simplex of the scalp maps to chromosome 6p21.3. Am J Hum Genet 2000; 66: 1979-1983.

7 Unna M: Ueber Hypotrichosis congenita hereditaria. Derm Wschr 1925; 81: 1167-1178.

8 Argenziano G, Sammarco E, Rossi A, Delfino M, Calvieri S: Marie Unna hereditary hypotrichosis. Eur J Dermatol 1999; 9: 278-280.

9 Sreekumar GP, Roberts JL, Wong C-Q, Stenn KS, Parimoo S: Marie Unna hereditary hypotrichosis gene maps to human chromosome 8p21 near hairless. J Invest Dermatol 2000; 114: 595-597.

10 Lefevre P, Rochat A, Bodemer C et al: Linkage of Marie Unna hypotrichosis locus to chromosome 8p21 and exclusion of 10 genes including the hairless gene by mutation analysis. Eur J Hum Genet 2000; 8: 273-279.

11 Baumer A, Belli S, Trueb RM, Schinzel A: An autosomal dominant form of hereditary hypotrichosis simplex maps to $18 \mathrm{p} 11.32$ p11.23 in an Italian family. Eur J Hum Genet 2000; 8: 443-448.

12 Winter $\mathrm{H}$, Labreze $\mathrm{C}$, Chapalain $\mathrm{V}$ et al: A variable monilethrix phenotype associated with a novel mutation, glu402lys, in the helix termination motif of the type II hair keratin hHb1. J Invest Dermatol 1998; 111: 169-172.

13 Segre JA, Nemhauser JL, Taylor BA, Nadeau JH, Lander ES: Positional cloning of the nude locus: genetic, physical, and transcription maps of the region and mutations in the mouse and rat. Genomics 1995; 28: 549-559.

14 Frank J, Pignata C, Panteleyev AA et al: Exposing the human nude phenotype. Nature 1999; 398: 473-474.

15 Netherton EW: A unique case of trichorrhexis nodosa: 'bamboo hairs'. Arch Dermatol 1958; 78: 483-487.

16 Smith DL, Smith JG, Wong SW, de Shazo RD: Netherton's syndrome: a syndrome of elevated IgE and characteristic skin and hair findings. J Allergy Clin Immunol 1995; 95: 116-123.

17 Chavanas S, Garner C, Bodemer C et al: Localization of the Netherton syndrome gene to chromosome 5q32, by linkage analysis and homozygosity mapping. Am J Hum Genet 2000; 66: 914-921.

18 Schaffer AA: Fast linkage analysis computations for pedigrees with loops or unused alleles. Hum Hered 1996; 46: 226-235.

19 Nothen MM, Cichon S, Vogt IR et al: A gene for universal congenital alopecia maps to chromosome 8p21-22. Am J Hum Genet 1998; 62: 386-390.

20 Ho L, Williams MS, Spritz RA: A gene for autosomal dominant hypohidrotic ectodermal dysplasia (EDA3) maps to chromosome 2q11-q13. Am J Hum Genet 1998; 62: 1102-1106.

21 Suzuki K, Bustos T, Spritz RA: Linkage disequilibrium mapping of the gene for Margarita Island ectodermal dysplasia (ED4) to 11q23. Am J Hum Genet 1998; 63: 1102-1107.

22 Kibar Z, Kaloustian VMD, Brais B et al: The gene responsible for Cloustan Hydrotic ectodermal dysplasia maps to the pericentromeric region of chromosome 13q. Hum Mol Genet 1996; 5: 543-547.

23 Healy E, Holmes SC, Belgaid CE et al: A gene for monilethrix is closely linked to the type II keratin gene cluster at 12q13. Hum Mol Genet 1995; 4: 2399-2402.

24 Krebsova A, Hamm H, Karl S et al: Assignment of the gene for a new hereditary nail disorder, isolated congenital nail dysplasia, to chromosome 17p13. J Invest Dermatol 1999; 115: 664-667.

25 Broman KW, Murray JC, Sheffield VC et al: Comprehensive human genetic maps: individual and sex-specific variation in recombination. Am J Hum Genet 1998; 63: 861-869.

26 Simrak D, Cowley CME, Buxton RS, Arnemann J: Tandem arrangement of the closely linked desmoglein genes on human chromosome 18. Genomics 1995; 25: 591-594. 
27 King IA, Sullivan KH, Bennett RS, Buxton RS: The desmocollins of human foreskin epidermis: identification and chromosomal assignment of a third gene and expression patterns of the three isoforms. J Invest Dematol 1995; 105: 314-321.

28 Townes TM, Behringer RR: Human globin locus activation region (LAR): role in temporal control. Trends Genet 1990; 6: 219-229.

29 Grunwald GB: The structural and functional analysis of cadherin calcium-dependent cell adhesion molecules. Curr Opin Cell Biol 1993; 5: 797-805.

30 Silos SA, Tamai K, Li K et al: Cloning of the gene for human pemphigus vulgaris antigen (Desmoglein 3), a desmosomal cadherin. J Biol Chem 1996; 271: 17504-17511.
31 Karpati S, Amagai M, Prussick R, Stanley JR: Pemphigus vulgaris antigen is a desmosomal desmoglein. Dermatology 1994; 189: $24-26$.

32 Calvanico NJ, Martins CR, Diaz LA: Characterization of pemphigus foliaceous antigen from human epidermis. $J$ Invest Dermatol 1991; 96: 815-821.

33 Hashimoto T, Kiyokawa C, Mori O: Human desmocollin 1 (DSC1) is an autoantigen for the subcorneal pustular dermatosis type IgA pemphigus. J Invest Dermatol 1997; 109: 127-131.

34 Koch PJ, Mahoney MG, Ishikawa H: Targeted disruption of the pemphigus vulgaris antigen (desmoglein 3 ) gene in mice causes loss of keratinocyte cell adhesion with a phenotype similar to pemphigus vulgaris. J Cell Biol 1997; 137: 1091-1102. 